\title{
EKLEMELİ İMALAT (3B BASKI): TEKNOLOJILER VE UYGULAMALAR
}

\author{
Hasan Kemal SÜRMEN*
}

Alınma: 22.11.2018; düzeltme: 03.04.2019; kabul: 05.04.2019

Öz: Hızlı prototipleme ve üç boyutlu (3B) baskı adlarıyla da bilinen eklemeli imalat, geleneksel bilgisayar destekli üretimdeki talaş kaldırma prensibinin tersine malzemelerin birleştirilerek katmanlar halinde oluşturulup üst üste eklenmesi prensibine dayanan, serbest formlu ve karmaşı geometrili objelerin üretilmesine imkan sağlayan pratik bir imalat metodudur. Günümüzde daha çok 3B bask1 olarak anılan bu yöntem, çatısı altında birçok farklı teknolojiyi barındırmaktadır. Ürünlerin farklı malzeme, mekanik ve geometrik özelliklerinden dolayı çeşitli eklemeli imalat teknolojileri geliştirilmiş ve ticarileştirilerek otomotiv, havacılık, biyomedikal, tıp, gıda, eğitim ve eğlence sektörlerinin kullanımına sunulmuştur. $\mathrm{Bu}$ yazıda eklemeli imalat teknolojileri ile ilgili detaylı bir derleme yapılmıştır. $\mathrm{Bu}$ kapsamda 3B baskı sürecindeki işlem adımları izah edilmiş, günümüzde kullanılan popüler 3B baskı teknolojilerinin çalışma prensipleri açıklanmış ve karşılaştırılmaları yapılmıştır. Güncel uygulama alanlarına da yer verilen bu yazıda 3B baskı teknolojilerine ait bazı püf noktaları ve gelecek yönelimlerinden de bahsedilmiştir.

Anahtar Kelimeler: Eklemeli imalat, 3B baskı, Yöntemler, 3B yazıcı, Uygulama alanları, Teknolojiler

\section{Additive Manufacturing (3D Printing): Technologies and Applications}

\begin{abstract}
Additive manufacturing, also known as rapid prototyping and three-dimensional (3D) printing, is a practical method that enables the manufacturing of free-form objects with complex geometry, based on the principle of combining materials and building up layer-by-layer, in contrast to the subtractive manufacturing principle of the traditional computer-aided manufacturing. Nowadays, this method, which is mostly called 3D printing, collects many different technologies under its roof. Due to the different material, mechanical and geometric properties of the products, various additive manufacturing technologies have been developed, commercialized and introduced to the use of automotive, aerospace, biomedical, medical, food, education and entertainment sectors. In this paper, a comprehensive review of additive manufacturing technologies has been presented. In this context, general process steps of 3D printing and the working principles of the popular 3D printing technologies used today have been explained and compared to each other. Moreover, current application areas, some tips and future trends related to $3 \mathrm{D}$ printing technologies have been also mentioned in the paper.
\end{abstract}

Keywords: Additive manufacturing, 3D printing, Methods, 3D printer, Applications, Technologies

\section{GíRiş}

Eklemeli (katmanlı) imalat metal, plastik, kompozit ve organik malzemeler kullanılarak objelerin üç boyutlu (3B) geometrik verilerine göre oluşturulan katmanlarının üst üste eklenmesi prensibine dayanan pratik bir imalat yöntemidir. Eklemeli imalat önceden daha çok prototip üretimi için kullanılan bir yöntem olan hızlı prototipleme adıyla anılmaktaydı. Bu

\footnotetext{
* İstanbul Üniversitesi-Cerrahpaşa, Teknik Bilimler Meslek Yüksekokulu, 34500, Büyükçekmece-İstanbul İletişim Yazarı: Hasan Kemal Sürmen (hasan.surmen@istanbul.edu.tr)
} 
yöntem ilk olarak 1980'lerde 3B Systems şirketi tarafından stereolitografi (StereolithographySL) teknolojisi ile ortaya çıkmıştır (Jacops, 1992). O yıllarda birçok eklemeli imalat yöntemi geliştirilmiş ve patent başvuruları yapılmıştır. Daha sonra bu teknolojiler şirketler tarafindan ticarileştirilmiştir. SL'yi takiben 1990'ların ilk yarısında Helysis şirketi lamine nesne imalatı (Laminated Object Manufacturing-LOM), Stratasys şirketi eriyik yığarak modelleme (Fused Deposition Modeling-FDM), DTM şirketi seçmeli lazer sinterleme (Selective Laser SinteringSLS), EOS şirketi doğrudan metal tozu lazer sinterleme (Direct Metal Laser Sintering-DMLS), Cubital şirtketi katı zemin kürleme (Solid Ground Curing-SGC) ve Soligen şirketi 3B bask1 (Three Dimensional Printing-3DP) teknolojilerini ticarileştirerek piyasaya sürmüşlerdir (Danforth ve Safari, 1996; Wohlers ve Gornet, 2014). 3B bask1 (3DP) prosesi de aslinda Massachusetts Institute of Technology (MIT) tarafindan lisansı alınmış bir eklemeli imalat teknolojisidir. Bir dilimleme yazılımıyla üretilmiş olan 3B veriye göre hareket eden nozülden bir sıvı bağlayıcı, toz yatağında bulunan toz malzemenin üzerine püskürtülerek bir katman oluşturulur. Daha sonra toz yatağı katman kalınlığı kadar aşağıya indirilerek üzeri toz malzeme ile sıvanır ve katılaştırma işlemi geometrik veriye göre tekrarlanarak, yeni katman var olan katmanın üzerine oluşturulur. Bu şekilde objenin tamamı elde edilir ve yapıştırılmayan tozlar temizlenir (Yan ve $\mathrm{Gu}, 1996$ ). Bu teknoloji 2 boyutlu yazıcılarda kullanılan inkjet bask1 teknolojisine benzerliği nedeniyle 3B baskı olarak adlandırılmış ve bu teknoloji ile çalışan makinelere 3B yazıcı adı verilmiş̧ir. Daha sonraları benzer mantıkla çalışan teknolojiler geliştirilmiş ve bu teknolojiler masaüstü makinelere aktarılarak ev ve ofislerde geniş kitlelerin kullanımına açılmıştır. Kullanımı yayılan bu teknolojilerin dayandığı üretim yöntemleri halk arasında 3B baskı (3D printing) adı ile tanınmış, eklemeli imalat ve hızlı prototipleme terimleri de 3B baskı olarak anılmaya başlanmıştır.

Bir çok farklı teknolojiyi çatısı altında bulunduran 3B baskı, dijital ortamda tasarlanmış olan objeleri eklemeli imalat yöntemleri kullanılarak fiziksel objelere dönüştürülmesine imkan veren pratik bir imalat yöntemidir. 3B baskının temel mantığı olan katmanlı imalat, CNC frezeleme ve tornalama gibi bilgisayar destekli üretim proseslerinin dayandığ 1 talaşlı imalat yönteminin tersidir. Talaşlı imalatta üç boyutlu nesne bir malzeme bloğundan parçalar kesilip uzaklaştırılması ile elde edilir. 3B baskı yönteminde ise tasarlanan üç boyutlu nesne art arda oluşturulan malzeme katmanlarının birleştirilmesi ile elde edilir. Bu nedenle eklemeli imalat yöntemi ile üç boyutlu objeler daha az malzeme kullanılarak elde edilebilmektedir. Üretim hattı kurulumu, kalıp tasarımı gibi ek üretim aşamaları gerektirmemesi ve tasarımın hemen imalata alınabilmesi 3B baskı teknolojisinin tercih edilmesindeki en önemli nedenlerdir. Aynı zamanda eklemeli imalatın sağladığı avantajları kullanarak yüksek geometrik doğruluk ve çözünürlükte 3 boyutlu imalat yapabilme becerisine sahip ev tipi masaüstü 3B yazıcıların geliştirilmesi bu teknolojinin diğer imalat yöntemleri arasında öne çıkmasında etkili olmuştur. Ayrıca eklemeli imalat konseptinin sağladığ 1 üretim esnekliği serbest formlu yüzeylere sahip objelerin üretiminde büyük avantaj sağlamaktadır. 3B baskı yöntemiyle çalışan yazıcıların sağladığı bir diğer avantaj ise bulut tabanlı üretime imkan vermeleridir. Bu sayede gelen siparişler yazıcıya iletilerek ve herhangi bir kalıp veya hat ihtiyacı olmadan doğrudan üretim kabiliyetine sahip 3B yazıcılar ile üretim hızlı bir şekilde gerçekleşebilmektedir. 3B yazıcıların, bulut teknolojisinin yanı sıra sensör, kablosuz iletişim, robot kol gibi teknolojileri içeren endüstri 4.0 için çok önemli bir yere sahip olacağı anlaşılmaktadır. 3B baskı yönteminin bütün avantajlarına rağmen seri üretim için ekonomik olmaması, imal edilecek parçanın 3B yazıcının boyutları ile sınırlı kalması ve üretim hızının düşük olması yönteminin kullanımını kısıtlamaktadır. Ayrıca 3B baskıda kullanılan malzeme çeşidi de sınırlıdır. Ancak her geçen gün farklı malzemelerin kullanılmasına olanak sağlayan yeni yöntemler ve teknolojiler geliştirilmektedir. Günümüzde artık birçok plastik, metal, kompozit ve organik malzeme çeşidi 3B baskı imalatında kullanılabilmektedir. 2018 yılında kullanıcıların en çok tercih ettiği 3B yazıcı teknolojileri ve malzemeler sirasiyla Şekil 1 ve Şekil 2'de Scupteo'nun (2018) "The State of 3D Printing" raporuna göre düzenlenerek aktarılmıştır. Bundan sonraki bölümlerde eklemeli imalat işlem 
adımları, eklemeli imalat teknolojileri ve uygulama alanlarından bahsedilmiş, sonuç bölümünde de genel bir değerlendirme yapılmıştır.

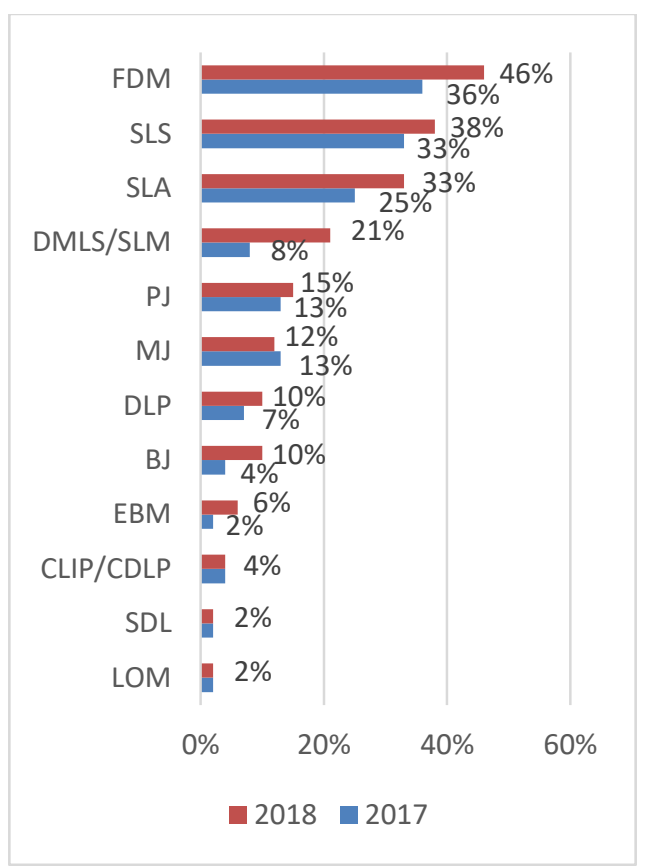

Şekil 1:

2017-2018 yıllarında en çok tercih edilen 3B yazıcı teknolojileri

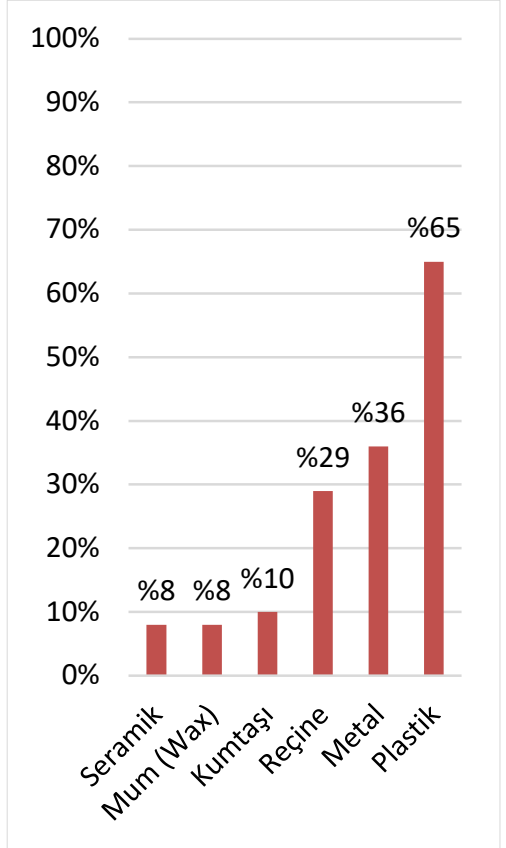

Şekil 2:

2018 yılında en çok kullanılan $3 B$ baskı malzemeleri

\section{EKLEMELİ İMALAT (3B BASKI) İŞLEM ADIMLARI}

Hat kurulumu ve kalıp ihtiyacı olmadan, doğrudan tasarımından üretime geçişe imkan veren 3B baskı prosesi genel olarak altı temel adımdan oluşur (Şekil 3).

\section{B BASKI ADIMLARI}

\begin{tabular}{|c|c|c|c|c|c|}
\hline $\begin{array}{c}\text { 3B } \\
\text { Modelleme }\end{array}$ & $\begin{array}{c}\text { Dosya } \\
\text { Kaydetme }\end{array}$ & Dilimleme & $\begin{array}{l}\text { Dosya } \\
\text { Transferi }\end{array}$ & 3B Bask1 & Son-İșlem \\
\hline $\begin{array}{l}\text { 3B çizim, } \\
\text { 3B tarama }\end{array}$ & $\begin{array}{l}\text { STL, } \\
\text { OBJ, } \\
\text { X3D, } \\
3 \mathrm{MF}\end{array}$ & $\begin{array}{l}\text { Malzeme tipi, } \\
\text { Katman kalınlığ1, } \\
\text { Bask1 yoğunluğı, } \\
\text { Bask1 s1caklığ1, } \\
\text { Bask1 hızı, } \\
\text { Obje konumu, } \\
\text { G-kod }\end{array}$ & $\begin{array}{c}\text { Çıkarılabilir disk, } \\
\text { Ağ üzerinden } \\
\text { transfer }\end{array}$ & $\begin{array}{c}\text { Malzemenin } \\
\text { yazıcıya } \\
\text { yüklenmesi, } \\
\text { Kalibrasyon ayar1, } \\
\text { Sicaklik ayarı }\end{array}$ & $\begin{array}{c}\text { Destek yapiların } \\
\text { sökülmesi, } \\
\text { Zımparalama, } \\
\text { Polisaj, } \\
\text { Boyama, } \\
\text { Dolgu yapma, } \\
\text { Epoksi kaplama }\end{array}$ \\
\hline
\end{tabular}

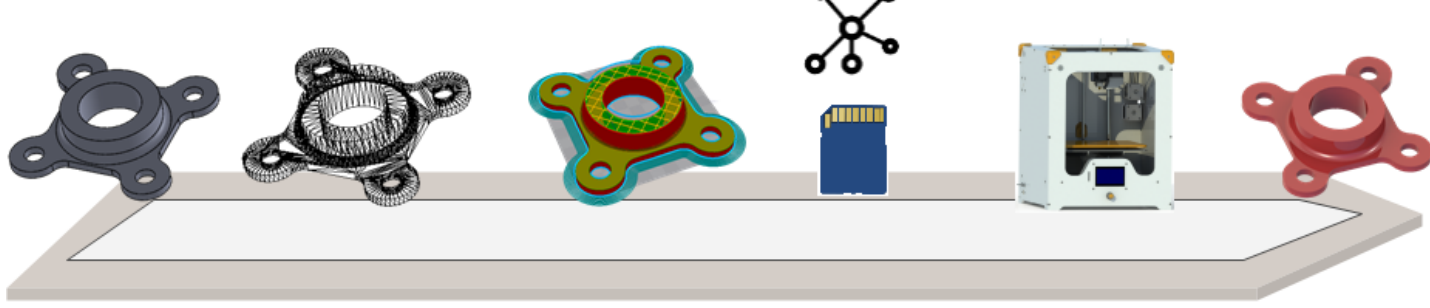

Şekil 3:

Eklemeli imalat (3B baskı) işlem adımları 
$\mathrm{Bu}$ adımlar sırasıyla; üretilmek istenen objenin 3B modelinin dijital olarak elde edilmesi, model dosyasının dilimleme yazılımı için uygun bir dosya formatına dönüştürülmesi, modelin dilimleme yazılımına aktarılarak katmanlara ayrılması ve G-kodlarının çıkartılması, elde edilen G-kodların 3B yazıcıya aktarılması, baskı işlemi için 3B yazıcının hazırlanması ve baskılamanın başlatılıp fiziksel objenin elde edilmesi ve son olarak elde edilen objenin destek yapılarından temizlenmesi ve son-işlem adımlarının uygulanmasıdır.

\subsubsection{B Modelleme}

3B baskı prosesinde ilk başta basılacak objenin üç boyutlu modeline ihtiyaç vardır. Model birçok farklı bilgisayar destekli tasarım (CAD) programları ile elde edilebileceği gibi bir 3B (lazer, optik, MR, CT, fotoğraf-tabanlı) tarama sistemi kullanılarak da elde edilebilir. Tasarımlar kullanılan 3B yazıcı teknolojisi yöntem ve yazıcının hassasiyeti dikkate alınarak yapılırsa daha verimli sonuçlar elde edilebilir. Destek yapıları kullanan teknolojilerde genel olarak $45^{\circ}$ kuralı geçerlidir. Bu kurala göre $45^{\circ}$ ye kadar genişleyen açılı yüzeyler destek yapılara ihtiyaç duymazken $45^{\circ}$ den sonra destek yapılar üzerine inşa edilebilirler (Şekil 4). Modelleme yapılırken $45^{\circ}$ kuralının dikkate alınması malzeme ve zamandan tasarruf edilmesine katk1 sağlar. Tek seferde basılması düşünülen montaj parçalarında hareketli parçaların aralarındaki boşluklar belirlenirken 3B yazıcının kabiliyetleri göz önünde bulundurulmalıdır. Eğer model bir 3B tarama sistemi ile elde edilmişse ise iyi analiz edilmeli, yüzey kusurları varsa bir mesh tamir yazılımında düzeltilmeli ve boyutları kontrol edilmelidir.

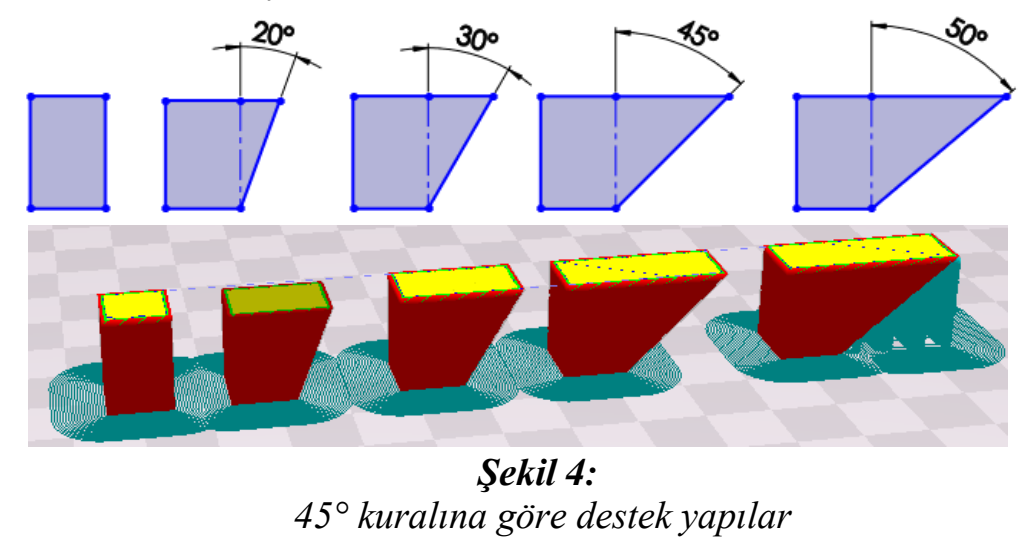

\subsection{Dosya kaydetme}

3B model elde edildikten sonra model aktarılacağı dilimleme yazılımının (slicer software) tanıyacağı bir dosya formatına dönüştürülmelidir. Bu işlem modelleme programının "save as" veya "export" seçenekleri kullanılarak yapılabileceği gibi dosya dönüştürücü yazılımlarla da yapılabilir. 3B baskı işlemlerinde en sık kullanılan dosya formatı STL'dir. Bunun dışında .obj, .X3D, .3MF gibi başka formatlar da birçok yazılım tarafından tanınmaktadır. Dosya dönüşümünden sonra model üzerinde değişiklik yapılamaz ancak modelin boyutu büyütülüp küçültülebilir ve yönü değiştirilebilir. Bununla beraber son zamanlarda STL formatındaki bir model üzerinde kısıtlı değişiklik yapılabilmesine imkan veren yazılımlar da (thinkerCAD) geliştirilmektedir.

\subsection{Dilimleme}

Uygun formatta kaydedilen modeller, 3B baskı işleminden önce bir 3B dilimleyici yazılıma aktartılır. Bu yazılımın amacı 3B nesneyi belirlenen katman kalınlığına göre dilimleyerek, 3B yazıcının objeyi inşa ederken ihtiyaç duyduğu G-kodlarını doğru bir şekilde elde etmektir. Yazılım sayesinde objenin 3B yazıcı tablası üzerindeki pozisyonu ve yönü, katman kalınlı̆̆ı, kullanılacak malzemenin cinsi, sıcaklık, baskı yoğunluğu, baskı hızı ayarlanabilmektedir. Parçanın baskı tablası üzerindeki yönü, baskı süresini ve harcanan malzeme miktarını doğrudan etkiler. Şekil 5'de görüldügü gibi parça yatay konumlandırıldığında daha az destek yapısına 
ihtiyaç duyulmuştur. Parçanın konumlandırılma biçimi aynı zamanda basım sonrasında destek yapıların temizlenmesi için harcanan emek ve zamanı da etkiler.

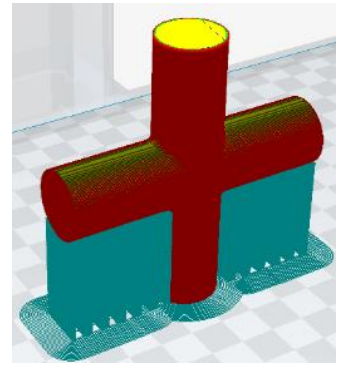

a.

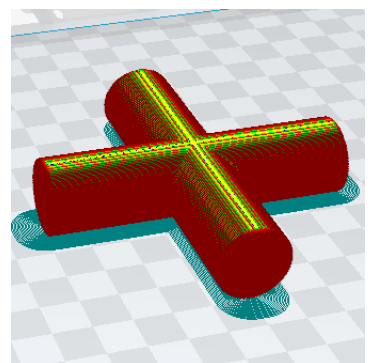

b.

Şekil 5:

Parçanın dilimleme yazılımında konumlandırılması. a. Dikey olarak konumlandırılmış parça.

(Baskl süresi 2 sa 21 dk, harcanan malzeme miktarl 21 gr'dır). b. Yatay olarak

konumlandırılmış parça. (Baskı süresi 2 sa $10 \mathrm{dk}$, harcanan malzeme miktarı $17 \mathrm{gr}$ 'dır.)

Bütün parametreler girildikten sonra model dilimlenir ve G-kodları üretilir. Bununla beraber modelin inşası simule edilerek izlenebilir. Böylece 3B baskı esnasında oluşabilecek hatalar önceden görülüp zamanında müdahale edilebilir. Birçoğu ücretsiz ve açık kod özelliğine sahip olan 3B dilimleyici yazılımlar (Cura, MatterControl, Slic3r, Craftware, Netfabb Basic vs.) çeşitli firmalar tarafından kullanıcıların hizmetine sunulmaktadır.

\subsection{Dosya Transferi}

3B dilimleme yazılımında elde edilen G-kodlarının 3B yazıcıya gönderilmesi, çıkarılabilir bellek vasıtasıyla veya kablolu/kablosuz bir ağ üzerinden gerçekleştirilebilir. Bu yüzden bir 3B yazıcı edinmeden önce kullanım koşulları dikkate alınmalı, kart okuma, kablolu bağlantı girişi ve kablosuz ağ erişimi gibi özellikler kontrol edilmelidir.

\subsubsection{B Baskı}

3B baskı işlemine başlamadan önce yazıcının düzgün bir zemin üzerinde olduğundan ve yazdırma tablasının yuvasına oturduğundan emin olunmalıdır. Daha sonra kalibrasyon ayarı ve malzeme yükleme işlemleri yapılabilir. Dosya aktarımı işlemi tamamlandıktan sonra Gkodlarını tanıyan 3B yazıcı gerekli sıcaklık değerine ulaştıktan sonra baskıya başlar. Sıcaklık ayarı manuel olarak 3B yazıcı menüsünden de yapılabilir. Baskı işlemi, kullanılan 3B yazıcı teknolojisine göre farklılıklar gösterir ve bask1 süresi değişebilir. Bask1 süresi aynı zamanda belirlenen baskı hızına, malzeme yoğunluğuna, modelin geometrisi ve boyutuna, kullanılan destek miktarı ve istenilen çözünürlük seviyesine göre de farklılık gösterebilir.

\subsection{Son-İşlem}

Baskı işlemi bittiğinde parça 3B yazıcı tablasından alınır ve destek yapılardan temizlenir. Destek yapıları standart ve çözülebilir olmak üzere iki çeşittir. Standart destek yapıları uygun el aletleri kullanılarak parçadan çıkartılır. Çözülebilen destek yapıları ise suda veya malzeme için geliştirilmiş solüsyonlar içinde bekletilerek temizlenir. Destekleri alınan parçaya daha sonra istenirse zımparalama, boyama, polisaj, epoksi kaplama, dolgu, yüzey buharlaştırma gibi parçanın yüzey özelliklerini geliş̧irmek amacıyla son-işlem uygulamaları yapılabilir.

\section{EKLEMELII İMALAT TEKNOLOJILERI}

Sik kullanılan eklemeli imalat teknolojileri Tablo 1'de kategorilere ayrılarak verilmiş ve teknolojilere ait başlıca özellikler belirtilerek karşılaştırmaları yapılmıştır (ASTM, 2012; Asadollahi ve diğ., 2016; Calignano ve diğ., 2017; Wimpenny ve diğ., 2017). 
Tablo 1. Eklemeli imalat teknolojilerinin karşılaştırılması

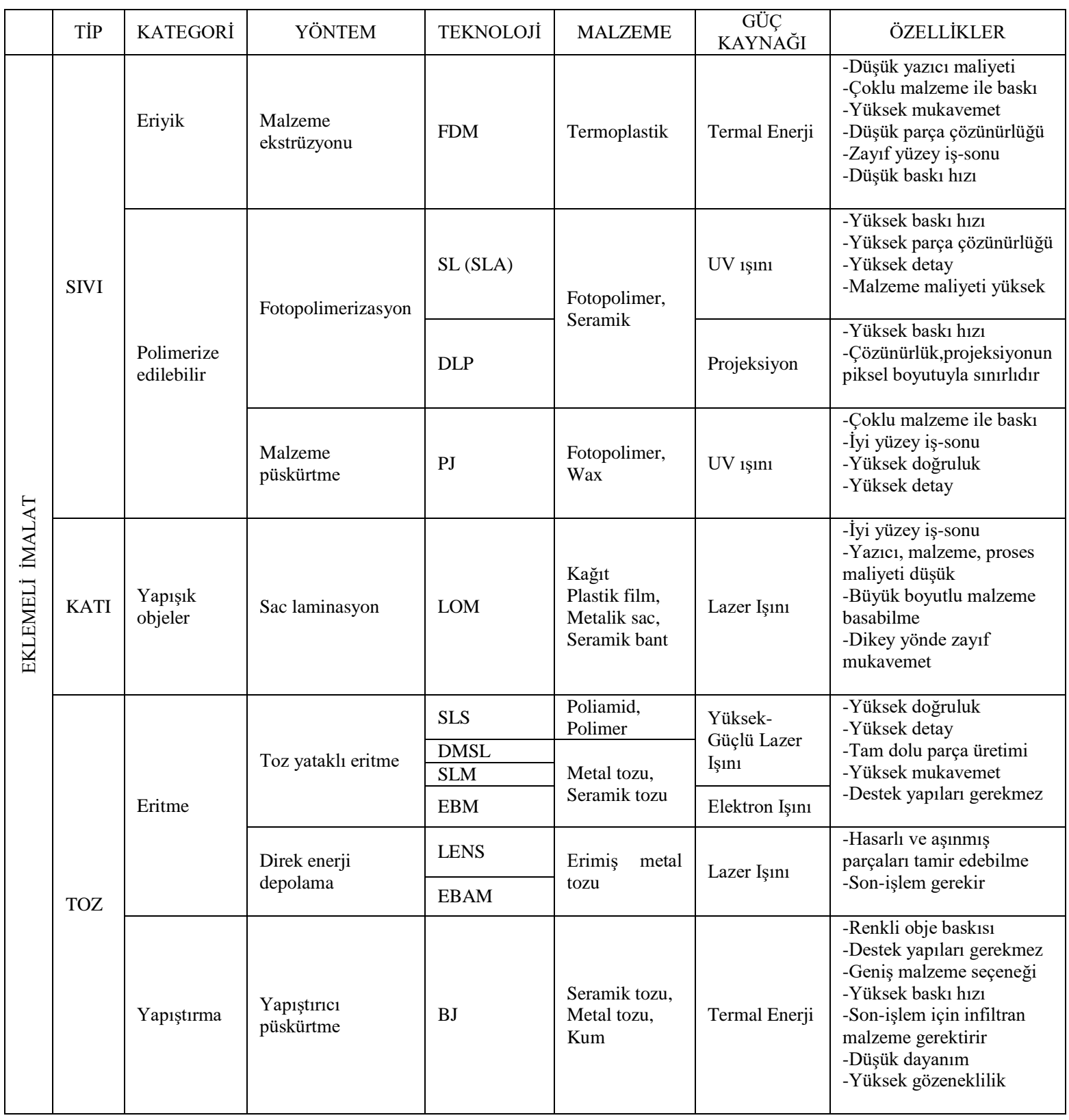

\subsection{Eriyik Yığarak Modelleme (Fused Deposition Modeling-FDM)}

FDM, 3B yazıcı denilince ilk akla gelen, bireysel kullanımı en yaygın eklemeli imalat teknolojisidir. Yaygın olarak kullanılmasında bu teknoloji ile çalışan birçok farklı masaüstü tipi yazıcı modelinin olması ve maliyetinin düşük olması etkilidir. Fused Filament Fabrication (FFF) diye de bilinen bu teknolojide makaralara sarılmış, genelde PLA, ABS ve karbon fiber malzemelerden elde edilmiş filamentler kullanılır. FDM yazıcılarda basımdan önce filamentin bir ucu ekstrüzyon kafasındaki yuvaya yerleştirilir ve filament makine tarafından nozülün ucuna doğru itilir. Burada filament 1sıtılarak basım sıcaklığına ulaşılır. Daha sonra filament ekstrüd edilerek basım tablasına doğru itilir (Şekil 6). Dilimleme programında elde edilen G-kodlarına göre nozül hareket ederek objeyi katman katman oluşturur (Crump, 1992). Bütün katmanların oluşturulması ile 3B obje tamamlanır ve basım tablasından sökülerek alınır. Proses birçok 3B yazıcı teknolojisinde olduğu gibi destek kısımlarının temizlenmesiyle son bulur. Birden fazla 
nozüllü FDM yazıcılar ile çok renkli basım yapılabileceği gibi ikinci nozül destek kısımlarını basmak için kullanılabilir. Destek yapıları için suda veya özel solüsyonlarda çözülebilen malzeme kullanımı özellikle karmaşı geometriler için büyük kolaylık sağlayabilir. Bu teknoloji ile elde edilen objenin dış yüzeyinde katman izleri görülebilir. Buna literatürde merdiven etkisi de denilmektedir (Gark ve diğ., 2016). Son-işlem aşamasında FDM baskı ile elde edilen parçalardaki bu etki ve yüzey pürüzlülügü zımparalama ve vaporizasyon ile azaltılabilir. $\mathrm{Bu}$ teknoloji ile elde edilen parçalar oldukça sağlamdırlar ve fonksiyonel olarak kullanılabilirler. FDM teknolojisi, basım hızının düşük olmasına rağmen, basılan parçanın üstün mekanik, termal ve kimyasal özelliklere sahip olması, kullanım kolaylığı, çevre dostu olması ve yazıcı maliyetinin düşük olması gibi nedenlerden dolayı diğer 3B basım teknolojilerine göre daha popüler olmuştur. Ancak FDM teknolojisinin düşük yüzey çözünürlügü̈, baskı hızı ve metal parçaların üretimi için uygun olmaması bazı alanlarda kullanımını kısıtlamıştır. Yine de FDM teknolojisi seramik ve metal tozlarının çeşitli termoplastiklerle karıştırılarak kullanımını mümkün k1lar (Dudek, 2013).

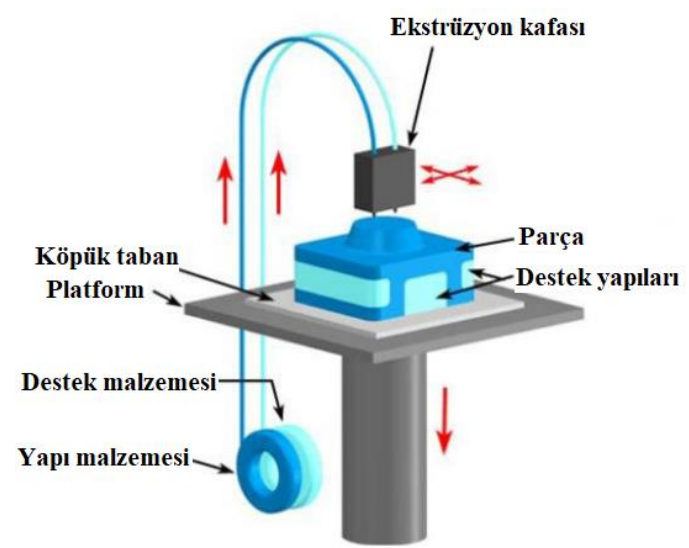

a.

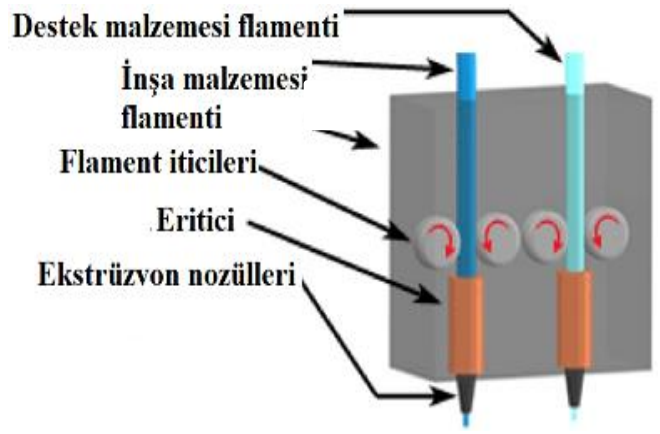

b.

Şekil 6:

a. FDM'nin çallşma prensibi b. Ekstrüzyon kafası (http://www.custompartnet.com/wu/fuseddeposition-modeling)

\subsection{Stereolitografi (Stereolithography-SL)}

SL teknolojisi oda sıcaklığında sıvı halde bulunan fotopolimer reçine tabakasının ultraviyole lazer 1şını vasıtasıyla geometrik veriye göre belirlenmiş olan bölgelerinin kürleştirilmesi prensibine dayanır (Hull, 1986). Kürleştirme işlemi 3B yazıcı teknolojilerinin esasını oluşturan eklemeli imalat mantığına göre yapılır. Her bir katman daha önceden bir 3B dilimleyici yazılımı kullanılarak oluşturulan G-kod verilerine göre elde edilir. $\mathrm{Bu}$ veriler doğrultusunda hareket eden lazer ışını reçine tabakasını tarayarak kürleştirme işlemini yapar. İlk katman katılaştırıldıktan sonra inşa platformu bir katman yüksekliği kadar hareket eder ve üstüne yeni bir reçine katmanı sıvanır ve kürleştirme işlemi tekrarlanır (Şekil 7). Katmanlar üst üste eklenerek objenin tamamı imal edilir. Bu şekilde belirli bir geometriye sahip olmayan sıv1 haldeki reçineden çok ayrıntılı geometrilere sahip üç boyutlu objeler elde edilebilmektedir. Yüksek doğruluk derecesine sahip, pürüzsüz yüzeylerin elde edilebildiği bu 3B baskı teknolojisi birçok alanda detaylı objelerin üretimine son derece uygundur. Bununla beraber fotopolimer içinde seramik tozu süspansiyonları eklenerek, seramik-reçine karışımının lazer polimerizasyonu ile karmaşık şekiller de elde edilebilmektedir (Chaput ve Chartier, 2007).

\subsection{Dijital Işık İşleme (Digital Light Processing-DLP)}

DLP ve SL teknolojileri oldukça benzer iki teknolojidir. Temel farkları 1şık kaynaklarının farklı olmasıdır. DLP baskı teknolojisinde UV lazer yerine reçine havuzunun altında bulunan bir projektör vardır (Hornbeck, 1991). SL'de lazer 1şını katmanı tarayarak ilerlerken DLP'de 
projektör bir seferde bütün katman yüzeyine etki eder ve bu sayede daha hızlı baskı hızına ulaşılır (Şekil 8). Ancak yüksek çözünürlük istenen parçalarda SL daha uygundur. Çünkü DLP teknolojisinde projektörün yansıttığı her bir katmana ait imajlar piksellerden oluştuğu için katman kenarlarında küçük dörtgensel hacimler meydana gelir. DLP'de projektörün çözünürlüğü basım kalitesi ve basım hacmiyle doğrudan ilişkilidir.

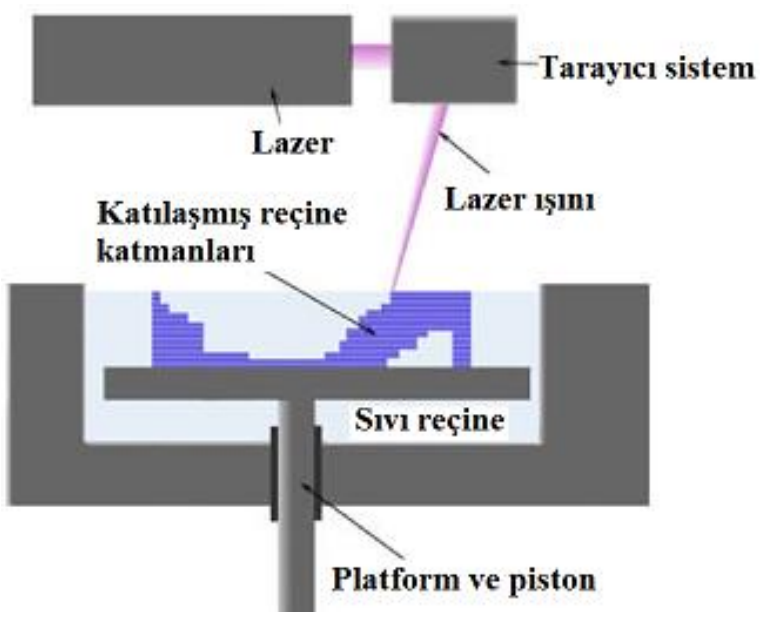

Şekil 7:

SL'nin çalışma prensibi

(Oropallo ve Piegl, 2016)

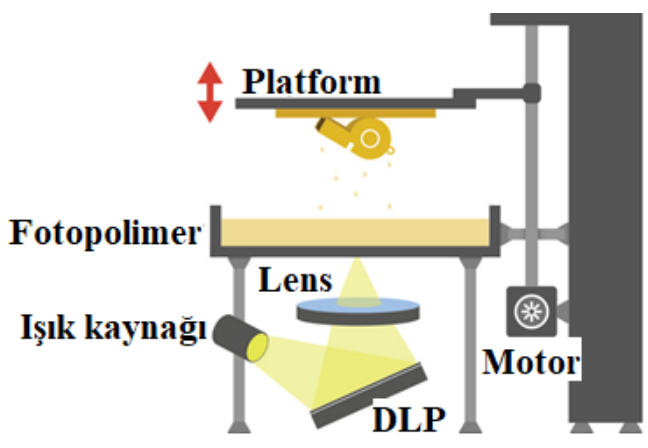

Şekil 8:

DLP'nin çalışma prensibi

(https://amtech3d.com/3d-printingtechniques/)

\subsection{Sürekli Dijital Işıık İşleme (Continuous Direct Light Processing-CDLP)}

Sürekli sıvı arayüz üretimi (Continuous Liquid Interface Production-CLIP) olarak da bilinen teknoloji dijital 1şık projeksiyonu, oksijen geçirgen mercekler ve programlanabilir sıv1 reçine kullanarak yüksek mekanik özelliklere sahip, yüksek çözünürlüklü parçalar üretmek için kullanılan yeni bir eklemeli imalat teknolojisidir. DLP teknolojisinin çalışma mantığına benzeyen CLIP'de inşa platformu Z ekseninde sürekli hareket halindedir. Böylece parçalar daha kısa sürede tamamlanabilir. Tumbleston ve diğ. (2015) CLIP teknolojisini kullanarak yaptıkları çalışmada 100 mikrometrenin altındaki çözünürlük değerlerinde onlarca santimetrelik monolitik polimerik parçaların sürekli üretimini göstermişlerdir. Sürekli sıv1 arayüz üretimi, fotopolimerizasyonun pencere ve polimerleştirici kısım arasında inhibe edildiği bir "ölü bölge" (kalıcı sıvı arayüzü) oluşturan UV projeksiyon düzleminin altındaki oksijeni geçiren bir pencere ile elde edilir. Ayrıca CLIP teknolojisi ile karmaşık katı parçalar, reçine kullanılarak $100 \mathrm{~mm} / \mathrm{saat}$ basım hızının üstünde bir hızla üretilebilmektedir. Bu basım hızı 3B baskının saatler yerine dakikalar içinde yapılabilmesine izin vermektedir. CLIP teknolojisinde yumuşak elastik malzemeler, seramikler ve biyolojik malzemeler kullanılabilmektedir (Tumbleston ve diğ., 2015).

\section{5. Çoklu Püskürtme (Polyjet -PJ)}

Fotopolimer reçine malzemesi ile 3B nesne üretiminde kullanılan diğer bir 3B bask1 teknolojisi de çoklu püskürtmedir. İnkjet teknolojisi mantığıyla çalışan bu teknoloji renkli parçalar üretmek için kullanılabilmesinin yanı sıra aynı anda birden fazla malzemeyi basabilen üstün ve baskı hızı yüksek bir teknolojidir (Wong ve diğ., 2012). Bu özelliği sayesinde basılan nesnenin istenen kısımları sert veya yumuşak olarak ayarlanabilir. Böylece tek parça üzerinde farklı mekanik özelliklere sahip kısımlar elde edilebilir. Pürüzsüz yüzeyli, detaylı geometrilere sahip parçaların üretiminde ideal olan bu teknoloji mürekkep püskürtmeli iki boyutlu yazıcıların bask1 sistemi ile SL bask1 teknolojisinin birleştirilmiş hali olarak düşünülebilir. Fotopolimer reçine basım tablasına püskürtülürken UV ışını kullanılarak kürleştirme işlemi yapılır ve diğer 
3B basım teknolojilerinde olduğu gibi oluşturulmuş katmanın üzerine diğer katman eklenerek parçanın üretimi tamamlanır (Şekil 9). Aynı anda farklı malzemelerin kullanımına izin veren polijet teknolojisi sayesinde destek yapıları kolay temizlenebilen, hatta su ile çözülebilen formda hazırlanabilmektedir (Adamidis ve diğ., 2018). Böylece destek kısımlarının temizlenmesi zahmetsiz olmakta ve temizleme işlemi sonunda yüzeylerde iz oluşmamaktadır.

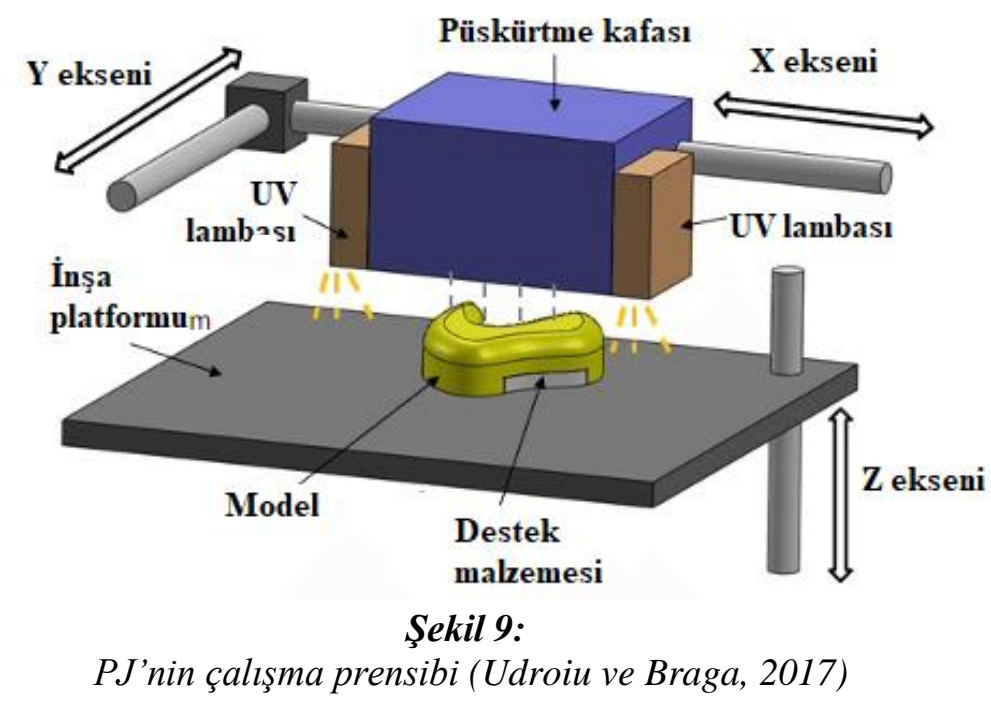

\subsection{Lamine Nesne İmalatı (Laminated Object Manufacturing - LOM)}

LOM bir parçanın imalatında ekleme ve çıkartma tekniklerinin beraber kullanıldığı bir teknolojidir. Kullanılan malzemeler sac formundadır. Kağıt, plastik film, metalik sac ve seramik bant LOM teknolojisinde en s1k kullanılan malzemelerdir. Karbondioksit tabanlı lazer kullanılarak sac formundaki malzeme, dilimleme programında elde edilen üç boyutlu geometrik veriye göre kesilir. Kesme işleminden sonra malzemenin bulunduğu platform sac kalınlığı kadar $(0,05 \mathrm{~mm}-5 \mathrm{~mm})$ aşağı indirilir ve üzerine yeni sac malzeme getirilir. Katmanlar termal bir bağlayıcı kullanarak basınç ve 1sıtma işlemleri ile birbirine yapıştırılırlar (Şekil 10). Kesilen kısım bir sonraki katman için destek görevi görür (Ramya ve Vanapalli, 2016). 3B obje elde edilene kadar bu işlem devam eder. Son-işlem ve destek yapılara ihtiyacının olmaması, proses esnasında malzeme yapısında herhangi bir deformasyonun oluşmaması ve düşük maliyet LOM teknolojisinin başlıca avantajlarıdır. Kesilen malzemenin yeniden değerlendirilmemesi durumunda israf olması, düşük yüzey çözünürlüğü ve karmaşık iç boşluk ve kanallar içeren parçaların üretiminin zor olması bu teknolojinin dezavantajları arasında sayılmaktadır (Wong ve Hernandez, 2012).

\subsection{Seçmeli Lazer Sinterleme (Selective Laser Sintering-SLS)}

SLS teknolojisi toz halde bulunan malzemenin bir lazer ışını ile sinterlenerek birleştirilmesi prensibine dayanır. SLS teknolojisinde malzeme tozları tamamen eritilmeden birbirine kaynaştırılır (Beaman ve Carl, 1990). Sinterlenmeyen tozlar ise destek görevi görürler ve prosesin sonunda parça tozlardan temizlenerek çıkartılır (Şekil 11). SLS teknolojisi metal, naylon, seramik, cam gibi çok çeşitli malzemelerin kullanılmasına imkan verir. SLS ile üretilen parçalarda iç gerilmeler oluşabilir. Bunun için gerilme giderme tavlaması yapılabilir. 3B bask1 sektöründe popüler olan bu teknoloji güçlü bir lazer kaynağına ihtiyaç duyar, bu da teknolojinin maliyetini artırır. $\mathrm{Bu}$ yüzden ev kullanıcıları arasında ve küçük ofislerde kullanılması yaygınlaşmamıştır. 


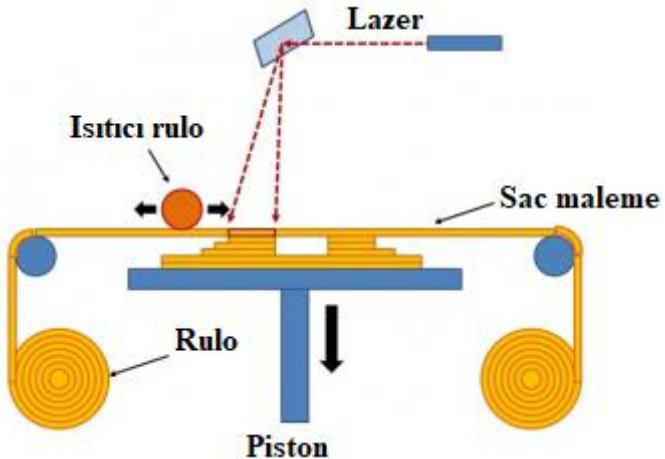

Şekil 10:

LOM'un çalışma prensibi

(https://prattparametrics.com/2017/09/18/3dprinting-research-6/)

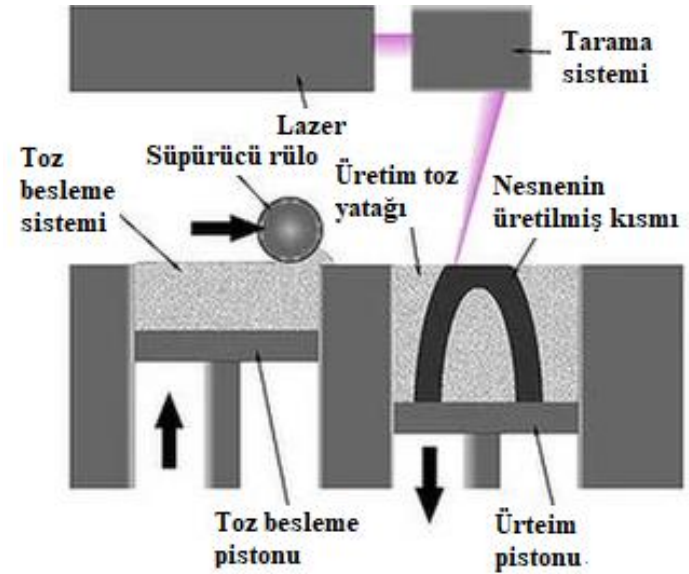

Sekil 11:

SLS'nin çalışma prensibi

(https://prattparametrics.com/2017/09/18/3dprinting-research-6/)

\subsection{Direk Metal Lazer Sinterleme (Direct Metal Laser Sintering-DMSL)}

SLS teknolojisinde yapılan bazı değişikliklerle "doğrudan metal lazer sinterleme" teknolojisi ortaya çıkmıştır (Agarwala ve diğ., 1995). Bu teknoloji ile mikro boyutta kaynaştırma ve ince yapıların üretiminde oldukça iyi sonuçlar alınabilmektedir. 3B yazıcılarla metal parça imalatında en etkili yöntemlerden biridir. Birçok metal alaşımı bu teknoloji için uygundur. DMLS teknolojisinin yüksek mukavemet, hizlı üretim ve malzemeden tasarruf edilmesi gibi avantajlarının olmasına karşın, yüksek enerji ihtiyacı, yüksek ilk yatırım maliyeti, iş-sonu işlemlerine ihtiyaç duyması gibi dezavantajları bulunmaktadır (Dupláková ve diğ., 2018).

\subsection{Seçmeli Lazer Ergitme (Selective Laser Melting-SLM)}

SLM, SLS teknolojisine çok benzeyen bir eklemeli imalat teknolojisidir. SLM'de sinterleme yerine tam bir eritme işlemi yapılır (Meiners ve Gasser, 2001). Havacılık ve medikal sektörlerinde popüler olan bu teknoloji yüksek maliyeti nedeniyle ev kullanıcıları için uygun değildir. SLM teknolojisinde en çok kullanılan malzemelerden biri yüksek biyo-uyumluluğa ve korozyon direncine sahip olan titanyumdur. Titanyum dışında paslanmaz çelik, alüminyum gibi metallerin de kullanıldığı SLM'de, SLS'de kullanılan plastik, cam, seramik gibi malzemeler uygun değildir. Yüksek güçlü lazer kullanan bu teknolojinin kontrolü kolay değildir. Proses esnasında sıcaklık kontrolünün iyi yapılması gerekir.

\subsection{Elektron Işınlı Ergitme (Electron Beam Melting-EBM)}

EBM teknolojisi, yüksek basınç atmosferi altında metal tozların veya filamentlerin yüksek enerji ve sıcaklık sağlayan odaklanmış bir elektron 1şını tarafından tamamen eritilmesi prensibine dayanır (Chua ve diğ., 2014). Geometrik veri dikkate alınarak birbirine kaynaştırılan tozlardan bir katman elde edilir ve bu katman bir platform vasıtasıyla seviye seviye aşağıya indirilir ve her indirilişinde üzeri metal tozları ile kaplanır ve kaynaştırma işlemi tekrarlanarak yeni katmanlar elde edilir. Bütün katmanlar birleştirilerek 3B obje elde edilir. EBM teknolojisinde vakum ortamı elektronların gaz molekülleri ile çarpışmasını önlerken reaktif metallerin prosesinde olumlu etki sağlar. Aynı zamanda önemli ölçüde enerji tüketiminin önüne geçilir. EBM yüksek mukavemetli parçaların üretiminde oldukça tercih edilen bir teknolojidir. Ayrıca EBM'de malzemenin ve baskı yatağının ön 1sıtılması ile artık gerilmelerin azaltılması, ışın parametrelerinin ayarlanmasıyla da parçanın gözeneklilik düzeyinin ayarlanması mümkündür. 


\subsection{Bağlayıcı (Yapıştırıcı) Püskürtme (Binder Jetting-BJ)}

Bu teknolojide malzemeleri birbirine birleştirmek için sıvı bağlayıcı bir malzeme kullanılır. Toz malzemenin üzerine bağlayıcı eklenerek birleştirme işlemi yapılır ve katı bir katman elde edilir (Hanssen ve diğ., 2013). Yazıcı platformu bir katman aşağıya indirilir ve toz malzeme daha önceden oluşturulmuş katmanın üzerine serilir. $\mathrm{Bu}$ işlemler bir döngü halinde gerçekleştirilerek objenin üretimi tamamlanır. Bu teknolojide metal, seramik, kum malzemeler kullanılabilir ve büyük parçaların imalatı için uygundur. BJ'de bir 1sıtma işlemi olmadığ için termal etkiden kaynaklanan boyutsal distorsiyonlar oluşmaz. Ayrıca SLS teknolojisinde olduğu gibi metal tozları destek görevi görürler ve bu yüzden destek yapılarına ihtiyaç duyulmaz. Geniş malzeme seçeneği sunan BJ teknolojisi renkli parçaların üretimine imkan verir ve düşük maliyet sunar. Ancak metal BJ teknolojisi ile basılan parçalar yüksek gözeneklilik gösterirler ve bu da parçaların mekanik özelliklerini olumsuz etkileyebilir. Basımdan sonra son-işlem gerekebilir ve parçanın kullanılmadan önce mekanik özelliklerinin artırılması için infiltran maddeye ihtiyaç duyulur. Seramik parçalar için bu madde genellikle siyanoakrilat yapıştırıcı, metal parçalar için bronz olarak seçilmektedir.

\subsection{Lazerle Net Şekillendirme (Laser Engineered Net Shape-LENS)}

$\mathrm{Bu}$ teknolojide lazer başlığı, toz malzemeyi dağıtan bir nozül ve inört gaz borusundan oluşan bir yığma ünitesi mevcuttur. İmalatın yapılacağı bölgede lazer ile bir eriyik havuzu oluşturulur ve havuza toz malzeme püskürtülür. Sonrasında malzeme soğuyarak katılaşır (Şekil 12-a). Bu işlem argon gazı ile dolu kapalı bir atmosfer içinde gerçekleşir. Bu teknoloji paslanmaz çelik, nikel alaşımları, takım çeliği, titanyum-6 alüminyum-4 vanadyum ve bakır alaşımları gibi çeşitli metaller için kullanılabilmektedir. Bunların dışında alümina malzemesi içinde uygun olan bu proses diğer yöntemlerle yapılması imkansız veya pahalı tamir işlemlerinde kullanılabilir. Ancak sıcaklık değişimleri ve soğutma işlemleri sonucunda parçalarda artık gerilmelerin oluşması türbin kanadı gibi hassasiyeti yüksek paçaların tamiri yapılırken dikkate alınması gereken bir durumdur (Wong ve Hernandez, 2012).

\subsection{Elektron Işınlı Eklemeli İmalat (Electron Beam Additive Manufacturing- EBAM)}

EBAM, metal parçalar üretmek için elektron 1şını ile metal tozu veya metal kablo malzemeleri kaynatarak birleştirmek amacıyla geliştirilmiş bir eklemeli imalat prosesidir. $\mathrm{Bu}$ prosesi LENS teknolojisinden ayıran nokta lazere göre daha verimli olan elektron işınının kullanılması ve prosesin vakum altında gerçekleştirilmesidir. EBAM teknolojisinin EBM teknolojisinden ayrıldığı nokta ise EBAM'ın toz yataklı bir proses olmayıp, toz malzemenin bir nozül vasitasıyla püskürtülmesi ve toz metal yerine metal kablo da kullanılabilmesidir (Şekil 12-b).

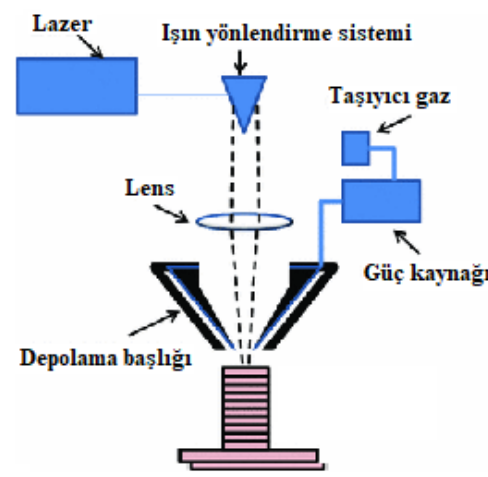

a.

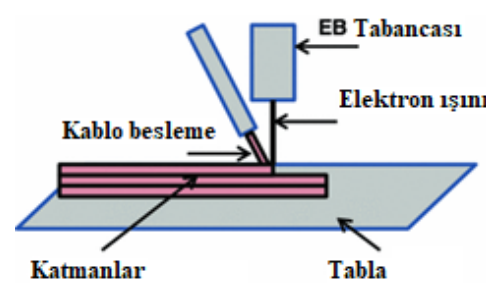

$b$.

Şekil 12:

Direk enerji depolama çalışma prensibi

a. Toz malzemeli sistem b. Kablo beslemeli sistem (Frazier, W. E. (2014) 


\subsection{B Biyobaskı}

Gelecekte en çok adından bahsedilecek 3B baskı teknolojilerinden biri de 3B biyobaskıdır. Doku mühendisliğinde araştırmacıların 3B baskı teknolojisinin avantajlarından faydalanmak istemeleri ile ortaya çıkmıştır. 3B biyobaskıda eklemeli imalat metotlarını kullanarak plastik, metal gibi malzemelerle 3B nesneler üreten $3 \mathrm{~B}$ yazıcı teknolojisi, malzemesi yaşayan hücreler olan dokuları basmak için adapte edilmiştir. 3B biyobaskı rejeneratif tıp uygulamalarında doku ve organ nakillerinde kullanılmak üzere geliştirilmiştir. $\mathrm{Bu}$ amaçla sıklıkla kullanılan teknolojiler termal inkjet (Cui ve diğ., 2012), mikroekstrüzyon (Panwar ve diğ., 2016) ve lazerdestekli baskıdır (Guillotin ve diğ. 2010). Hangi teknolojinin seçileceği malzemenin çeşidi, hücrenin yaşama yeteneği ve baskı yüzey çözünürlüğü dikkate alınarak belirlenir. Teknolojilerin her birinin birbirine göre bazı üstünlük ve kısıtlamaları bulunmaktadır. Termal inkjet teknolojili yazıcılar kolay bulunan, düşük maliyetli, yüksek çözünürlük ve hızlı baskı yapabilme özelliğine sahip yazıcılardır. Ancak kullanılan malzemeler likit formda olmalıdır. Ayrıca basım yoğunluğunun düşük olması da bu teknolojinin diğer bir kısıtlamasıdır. Mikroekstrüzyon teknolojisini kullanan yazıcılar ise yüksek hücre yoğunluklu basabilme özelliğine sahiptirler. Ayrıca bu teknoloji destek yapısından bağımsız doku oluşturmak için kullanılan en yaygın teknolojidir. Fakat uygulanan ekstrüzyon basıncına göre ters orantılı olan hücrenin hayatta kalma kabiliyeti oranı inkjet teknolojisine göre daha düşüktür. Bununla beraber bu teknolojide basım hızı ve çözünürlüğü artırmak için çalışmalar sürdürülmektedir. Diğer bir biyobaskı teknolojisi olan lazer-destekli baskıdır. Bu teknolojide geniş bir viskozite aralığında basım yapmak mümkündür. Ayrıca diğer teknolojilerde karşılaşılan nozülün malzemelerle tıkanması sorunu bu teknolojide ortaya çıkmaz. Ancak bu teknolojide yüksek çözünürlük için hızlı katılaşmaya ihtiyaç duyulur (Murphy ve Atala, 2014).

\section{EKLEMELI İMALAT TEKNOLOJILERININ UYGULAMA ALANLARI}

3B bask1; otomotiv, havacılık, medikal, eğitim, gıda, film ve eğlence sektörlerinde kullanım alanı her geçen gün genişleyen bir imalat teknolojisidir. Bu genişleme Wohlers 2018 raporuna da yansımıştır. Rapora göre 3B baskı endüstrisi 2017 'de $\% 21$ artış ile 7,3 milyar dolara ulaşmış, 2016 yıllındaki sektördeki büyüme \%17,4, 2015 yıllında ise \%25,9 olarak hesaplanmıştır (Wohlers Report, 2018).

Eklemeli imalat teknolojileri ilk önceleri birçok sektörde görsel bir doğrulama aracı olarak kullanılıyordu. Otomotiv endüstrisinde de parçaların prototiplerinin üretilmesi ile sınırlı olan teknoloji daha çok görsel analizler ve kalite kontrol amacıyla kullanılmaktaydı. 3B yazıcı kullanılarak üretilen Urbee aracından sonra otomotiv sektöründe eklemeli imalat ile araçlarda kullanılabilecek fonksiyonel son-ürün parçaların üretilebileceği fikri oluşmaya başlamıştır. Ev tipi 3B yazıcıların kullanılması ile fabrikalarda maliyetlerin ve tedarik süresinin düşürülebileceği ve aynı zamanda pres ve büyük şekillendirme makinelerinin kapladığı hacmin azaltılması ve üretim hattının sadeleştirilebileceği öngörülmektedir (Richardson ve Haylock, 2012).

Havacılık endüstrisinde de 3B baskı teknolojilerinden, özellikle operasyon zamanlarının azaltılmasında, üretim maliyetlerinin düşürülmesinde ve hava araçlarının imalatında kullanılan parçaların ağırlıklarının azaltılmasında faydalanılmaktadır (Huang ve diğ., 2016). Aynı zamanda 3B baskı yüksek teknoloji gerektiren hava araçlarının parçalarını üretme ve tamir etme yeterliliği olmayan ülkelerin kısa zamanda düşük maliyetle bu kabiliyete sahip olmalarında önemli bir firsat olarak görülmektedir (Wang ve diğ., 2018).

3B baskı teknolojilerinin fonksiyonel parça üretiminde profesyonel amaçlar için en yaygın kullanıldığı alanlardan biri biyomedikal sektörüdür. Biyomedikal cihazlar genellikle hastaya özel olarak tasarlanan, geleneksel imalat yöntemleri ile üretilmesi zor ve serbest formlu geometrik özelliklere sahip parçalardan oluşur. Bu tasarım özellikleri biyomedikal cihazların üretiminde 3B baskı teknolojilerinin kullanımını oldukça elverişli kılmaktadır. Bunun yanı sıra 3B tarama verileri ile beraber manyetik rezonans (MR) (Damianou ve di ̆. 2018) ve bilgisayarlı 
tomografi (CT) (Canzi ve diğ. 2018) ile yapılan taramalar sonucu elde edilen veriler kullanılarak 3B baskı ile üretim yapılabilmesi sektörde bu teknolojiye olan ilgiyi daha da artırmıştır. Günümüzde ortopedik implantlar, protezler, ortezler, diş sağlı̆g 1 ile ilgili ürünler ve birçok 3B cerrahi enstrüman 3B yazıcılar kullanılarak üretilebilmektedir (Cheriachan ve diğ., 2019; Ngo ve diğ., 2018). Aynı zamanda ilaç sektöründe tablet ve kapsüllerin üretimi de 3B bask1 teknolojileri ile yapılabilmektedir (Long ve diğ., 2017),

Bunların dışında 3B baskılamanın tıp sektörüyle buluştuğu diğer bir uygulama alanı ise 3B biyobaskıdır (Zhang ve diğ. 2018). 3B yazıcılar kullanılarak üç boyutlu, fonksiyonel, yaşayan dokular üretmek mümkün olmaktadır. Bu yazıcılarda genel olarak hidrojel, silikon, protein solüsyonları gibi malzemeler kullanılmaktadır. Bu alanda çalışan araştırmacıların en büyük amaçlarından biri yakın gelecekte fonksiyonel ve nakledilebilir insan organları üretmektir.

3B baskı teknolojisinin üç boyutlu, karmaşık geometrili bir modeli doğrudan fiziksel bir objeye dönüştürebilmesi ve serbest formlu objelerin üretimindeki başarısı gıda sektörünün de dikkatini çekmiştir. Sektör çalışanları müşterilerinin istekleri doğrultusunda özel tasarlanan yiyecek ürünlerinin imalatı ve artistik sunumlar için bu teknolojiden faydalanmaktadırlar (Lipton ve diğ., 2015). Bu alanda FDM'nin yanı sira SLS, SLA ve PJ eklemeli imalat teknolojileri de kullanılmaktadır.

Akademik çalışmalarda ve patent sürecinde prototip modellerin üretiminde yoğun bir şekilde kullanılan 3B baskı teknolojilerinden hem üniversitelerde hem de ilk ve orta ögretim eğitim kurumlarında proje tabanlı öğrenim, tasarım odaklı düşünme ve analitik düşünme becerilerinin geliştirilmesi gibi konularda eğitim ve öğretim alanında da faydalanılmaktadır (McMenamin ve diğ., 2014)

Scupteo'nun (2018) “The State of 3D Printing” raporuna göre hazırlanan Şekil 13'de kullanıcıların 3B baskı yöntemini hangi amaçlar için tercih ettiği gösterilmektedir. Ürün özelleştirmeden montaj sayısını azaltmaya kadar birçok farklı amaç için kullanılan 3B baskı teknolojilerinin en çok karmaşık serbest formlu objelerin üretimine ve kısa sürede tasarımdan üretime doğrudan geçişe olanak sağlamasından dolayı tercih edildiği görülmektedir. Şekil 14'de çeşitli eklemeli imalat teknolojileri ile üretilmiş ürünler gösterilmektedir.

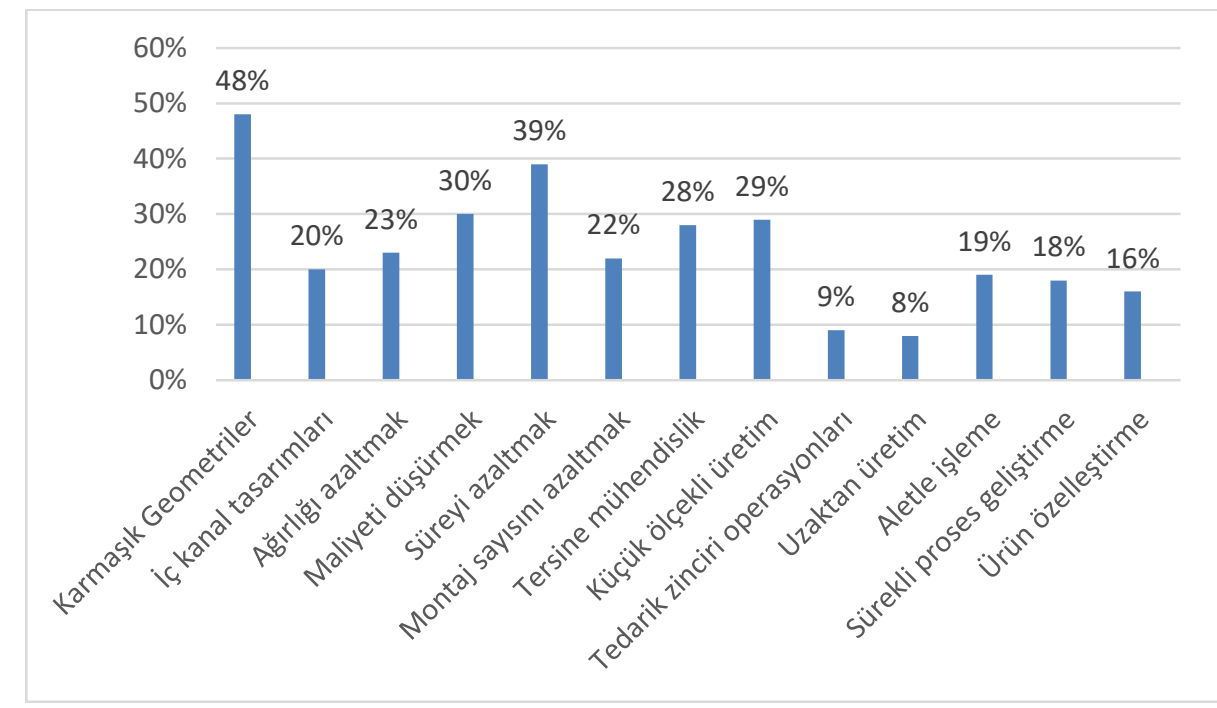

Şekil 13:

$3 B$ baskı yönteminin kullanım amaçları 


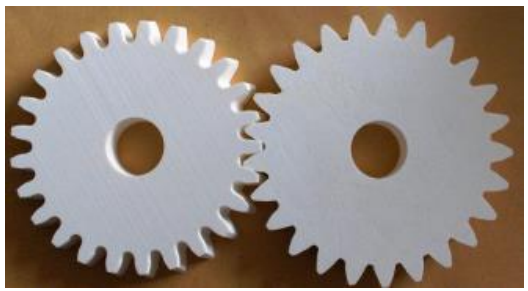

a)

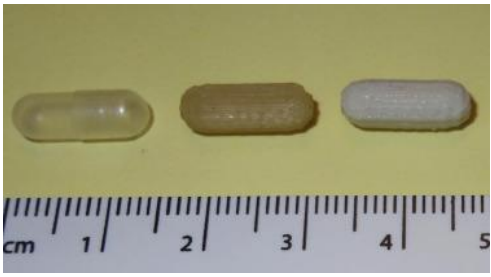

ç)

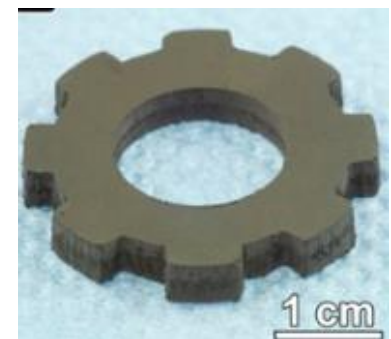

g)

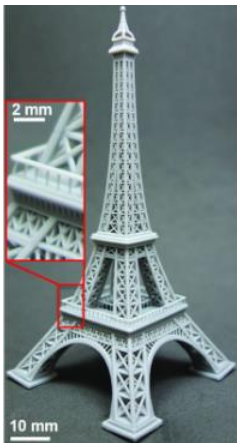

j)

k)

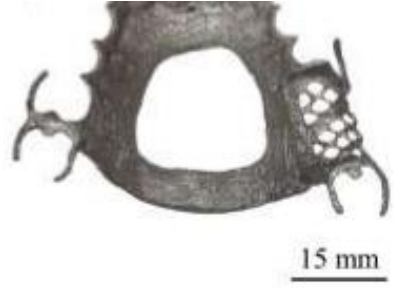

b)

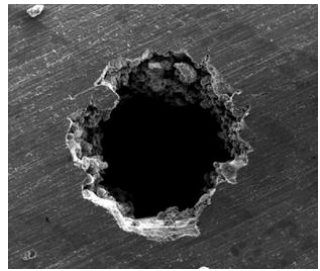

d)

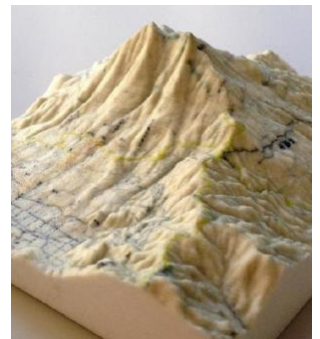

h)

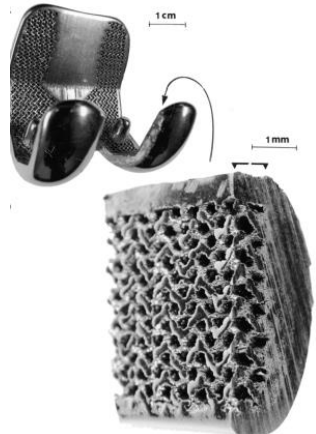

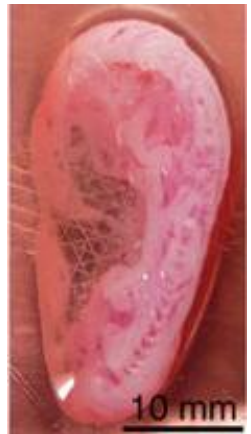

1)

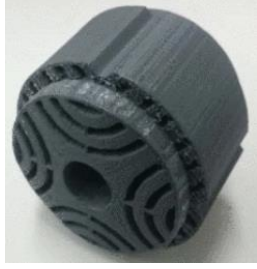

e)

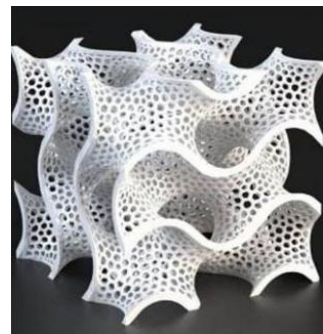

1)

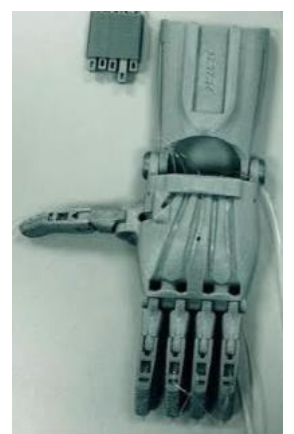

m)

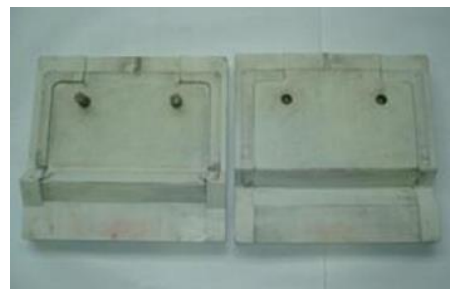

c)

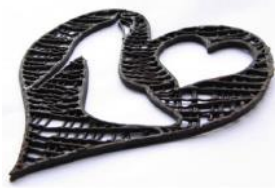

f)

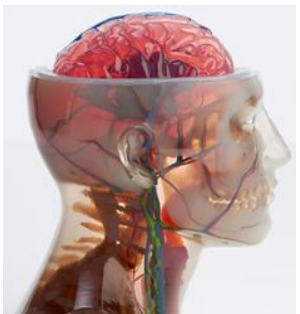

i)

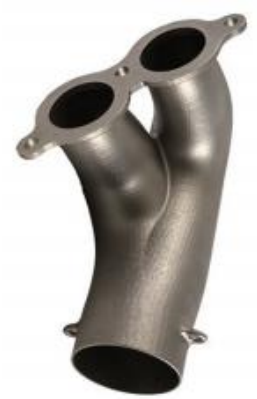

n)

Şekil 14:

a) FDM ile üretilmiş düz beveloid dişli (Fetvacl, 2018), b) BJ ile üretilmiş metal bölmeli diş protezi (Mostafaei ve diğ., 2017), c) FDM ile üretilmiş polikarbonat sac metal kalıb (Durgun,

2015), ç) FDM ile üretilmiş kapsül tipi ilaç tabletleri (Goyanes ve diğ., 2016), d) SLM ile AlSi10Mg alaşımından üretilmiş 0,5 mm çapında mikro kanal (Khan ve diğ., 2018), e)SLM ile üretilmiş rotor (Zhang ve giğ. 2016), f) SLS ile üretilmiş çikolata ürünü (Lipton ve diğ., 2015), g) LOM ile seramik banttan üretilmiş dişli (Krinitcyn ve diğ., 2017), h) LOM ile elde edilmiş bir kabartma model, ı) SLA ile elde edilmiş detayl mimari nesne (Marković ve Žıvković, 2016), i) PJ ile üretilmiş anatomik model (https://www.3dnatives.com), j) CLIP ile $100 \mathrm{~mm} / \mathrm{saat}$ basim hızıyla üretilmiş10 cm yüksekliğince Eiffel kulesi (Tumbleston ve diğ., 2015), k) EBM ile Co-

29Cr-6Mo alaşımından üretilmiş femoral implant (Murr ve di.̆. 2011), l) 3B biyobaskı yöntemiyle basılmış diş kulak (Kang ve diğ., 2016), m) FDM ile üretilmiş insan eli protezi (Ortes ve diğ., 2016), n) DMLS ile üretilmiş egzoz borusu flanşı (Dupláková ve diğ., 2018) 


\section{SONUC}

Geleneksel imalat metotları ile üretilmesi zor, detaylı ve serbest formlu geometrilere sahip parçaların üretimine imkan veren, üretim hattı kurulumu ve kalıp imalatı gerektirmeyen, operasyon zamanını azaltarak tasarımların hızlı bir şekilde ürünlere dönüşmesine olanak sağlayan 3B baskı teknolojilerinin kullanımı otomotiv, havacılık, eğitim, sağlık, gıda ve eğlence gibi birçok farklı alanda giderek yaygınlaşmaktadır. Günümüzde birçok şirket eklemeli imalatın sağladığı avantajlardan faydalanmak için eklemeli imalat teknolojilerine adapte olmaya başlamıştır (Rüßmann ve diğ., 2015). Üretim hatlarının değiştiği ve bilginin dijital olarak aktarıldığı bir çağda endüstrinin dördüncü devrimi (endüstri 4.0) ile eklemeli imalatın geniş çapta yayılacağı tahmin edilmektedir. Çünkü akıllı endüstri olarak da bilinen endüstri 4.0, 3B yazıcılarla son derece uyumlu olan nesnelerin interneti, hizmetlerin interneti, büyük veri, bulut tabanlı hesaplama, siber-fiziksel sistemler gibi bileşenlerden oluşmaktadır. Son dönemde hızla büyüyen 3B bask1 sektörünün pazar değerinin 2020 yılına kadar 21 milyar dolar olmas1 beklenmektedir (Niaki ve Nonino, 2018).

Eklemeli imalat yöntemi, karmaşık geometrili parçaların imalatı, hızlı tedarik ve operasyon, düşük maliyet, verimli malzeme kullanımı, özgül dayanımı yüksek ürünlerin üretilebilmesi, montaj aşamalarının sadeleştirilebilmesi, iç kanal ve boşluklara sahip parçaların üretilebilmesi, uzaktan üretim için uygun bir imalat yöntemi olması gibi birçok avantaja sahiptir. Seri üretime kıyasla eklemeli imalatta her parça bir birinden farklı geometrilerde üretilebilmekte, bu da üretimde büyük bir esneklik sağlamaktadır. Ancak yüksek sayılı üretimler dikkate alındığında eklemeli imalat seri üretimden daha maliyetli olmaktadır. Bunun yanı sıra bazı havacılık, sağlık gibi kritik öneme sahip alanlarda yüksek mekanik özellikli ve çözünürlüklü basım yapabilen 3B yazıcılar tercih edilmekte ve bu yazıcıların yüksek fiyatları bu teknolojinin kullanımını kısıtlamaktadır. Malzeme çeşidinin ve baskı boyutunun sınırlı olması, baskı işlemi bittikten sonraki son-işlem uygulamaları 3B baskı teknolojisinin diğer dezavantajları olarak karşımıza çıkmaktadır. Öte yandan şirketlerin ürün geliştirme bölümlerinde ve üniversitelerde yapılan araştırmalar ile eklemeli imalat teknolojileri sürekli olarak geliştirilmektedir. Eklemeli imalat ile detaylı geometrili, mikro boyutlu (Vaezi ve diğ., 2013), büyük boyutlu (Gosselin ve diğ., 2016) parçaların üretimi, geometrik hassasiyetin artırılması, mukavemetin artırılması (Han ve diğ., 2018; Wu ve di ğ., 2018), maliyetin düşürülmesi (Yang ve Li, 2018) ve kullanılan malzeme çeşidinin artırılması (Singh ve diğ. 2017) gibi birçok farklı alanda yapılan akademik çalışmalarla da teknolojik gelişmelere katkı sağlanmaya devam edilmektedir. Ayrıca son-işlem aşamasını kolaylaştırmak için tasarım konseptleri geliştirilmekte ve buna ilaveten kolay sökülebilen, sıvı içerisinde çözünebilen destek yapıları ile ilgili çalışmalara devam edilmektedir (Kim ve diğ., 2018; Swanson ve diğ., 2013). Önümüzdeki y1llarda yeni teknolojilerin geliştirilmesi, endüstri 4.0'a geçişin hızlanması ve eklemeli imalat yöntemiyle çalışan makinelerin daha çok yaygınlaşması ile 3B baskı maliyetinin daha da azalacağı, ayrıca 3B bask1 teknolojilerinin uçak, otomotiv, biyomedikal ve doku mühendisliğinde kritik bir öneme sahip olacağı anlaşılmaktadır.

\section{KAYNAKLAR}

1. Adamidis, O., Alber, S. ve Anastasopoulos, I. (2018). Investigation into 3D printing of granular media. Physical Modelling in Geotechnics, Proceedings of the 9th International Conference on Physical Modelling in Geotechnics, CRC Press, London, 113-118. doi:10.1201/9780429438660-9

2. Agarwala, M., Bourell, D., Beaman, J., Marcus, H. ve Barlow, J. (1995). Direct selective laser sintering of metals. Rapid Prototyping Journal, 1(1), 26-36. doi:10.1108/13552549 510078113 
3. Asadollahi-Yazdi, E., Gardan, J. ve Lafon, P. (2016). Integrated design in additive manufacturing based on design for manufacturing. Int'l Journal of Mechanical, Aerospace, Industrial, Mechatronic and Manufacturing Engineering, 10(6), 1104-1111.

4. ASTM Committee F42 on Additive Manufacturing Technologies \& ASTM Committee F42 on Additive Manufacturing Technologies. Subcommittee F42. 91 on Terminology. (2012). Standard terminology for additive manufacturing technologies. ASTM International. doi: 10.1520/F2792-09

5. Beaman, J. J. ve Deckard, C. R. (1990). U.S. Patent No. 4,938,816. Washington, DC: U.S. Patent and Trademark Office.

6. Calignano, F., Manfredi, D., Ambrosio, E. P., Biamino, S., Lombardi, M., Atzeni, E. ve Fino, P. (2017). Overview on Additive Manufacturing Technologies. Proceedings of the IEEE, 105(4), 593-612. doi: 10.1109/JPROC.2016.2625098

7. Canzi, P., Marconi, S., Manfrin, M., Magnetto, M., Carelli, C., Simoncelli, A. M. ve Benazzo, M. (2018). From CT scanning to 3D printing technology: a new method for the preoperative planning of a transcutaneous bone-conduction hearing device. Acta Otorhinolaryngologica Italica, 38, 251-256. doi: 10.14639/0392-100X-1625

8. Chaput, C. ve Chartier, T. (2007, August). Fabrication of ceramics by stereolithography. RTejournal-Forum für Rapid Technologie, 4(1).

9. Cheriachan, D. M., DiPaola, M., Iannotti, J. P. ve Ricchetti, E. T. (2019). 3D Printing in Orthopedics-Upper Extremity Arthroplasty. 3D Printing in Orthopaedic Surgery, 151-169. doi: 10.1016/b978-0-323-58118-9.00013-0

10. Chua, C. K. ve Leong, K. F. (2014). 3D Printing and Additive Manufacturing: Principles and Applications (with Companion Media Pack) of Rapid Prototyping Fourth Edition. World Scientific Publishing Company.

11. Crump, S. S. (1992). U.S. Patent No. 5,121,329. Washington, DC: U.S. Patent and Trademark Office.

12. Cui, X., Boland, T., DD'Lima, D. ve K Lotz, M. (2012). Thermal inkjet printing in tissue engineering and regenerative medicine. Recent patents on drug delivery ve formulation, 6(2), 149-155. doi: 10.2174/187221112800672949

13. Damianou, C., Giannakou, M., Yiallouras, C. ve Menikou, G. (2018). The role of threedimensional printing in magnetic resonance imaging-guided focused ultrasound surgery. Digital Medicine, 4(1), 22. doi: 10.4103/digm.digm_48_17

14. Danforth, S. C. ve Safari, A. (1996, August). Solid freeform fabrication: novel manufacturing opportunities for electronic ceramics. Applications of Ferroelectrics, 1996. ISAF'96., Proceedings of the Tenth IEEE International Symposium, 1, 183-188. doi:10.1109/isaf.1996.602732

15. Dudek, P. F. D. M. (2013). FDM 3D printing technology in manufacturing composite elements. Archives of Metallurgy and Materials, 58(4), 1415-1418. doi:10.2478/amm-20130186

16. Dupláková, D., Hatala, M., Duplák, J., Radchenko, S. ve Steranka, J. (2018). Direct Metal Laser Sintering-Possibility of Application in Production Process. Science and Research Journal, 1(4), 123-127. doi:10.18421/SAR14-01

17. Durgun, I. (2015). Sheet metal forming using FDM rapid prototype tool. Rapid Prototyping Journal, 21(4), 412-422. doi:10.1108/rpj-01-2014-0003 
18. Fetvaci, M. C. (2017). Determination of effective involute parameter limit in generation simulation of gears manufactured by rack-type cutters. Mechanics \& Industry, 18(4), 405. doi: $10.1051 / \mathrm{meca} / 2017028$

19. Frazier, W. E. (2014). Metal additive manufacturing: a review. Journal of Materials Engineering and Performance, 23(6), 1917-1928. doi:10.1007/s11665-014-0958-z

20. Garg, A., Bhattacharya, A. ve Batish, A. (2016). On surface finish and dimensional accuracy of FDM parts after cold vapor treatment. Materials and Manufacturing Processes, 31(4), 522-529. doi:10.1080/10426914.2015.1070425

21. Gosselin, C., Duballet, R., Roux, P., Gaudillière, N., Dirrenberger, J. ve Morel, P. (2016). Large-scale 3D printing of ultra-high performance concrete-a new processing route for architects and builders. Materials ve Design, 100, 102-109. doi:10.1016/j.matdes.2016.03.097

22. Goyanes, A., Kobayashi, M., Martínez-Pacheco, R., Gaisford, S. ve Basit, A. W. (2016). Fused-filament 3D printing of drug products: microstructure analysis and drug release characteristics of PVA-based caplets. International journal of pharmaceutics, 514(1), 290295. doi:10.1016/j.ijpharm.2016.06.021

23. Guillotin, B., Souquet, A., Catros, S., Duocastella, M., Pippenger, B., Bellance, S. ve Guillemot, F. (2010). Laser assisted bioprinting of engineered tissue with high cell density and microscale organization. Biomaterials, 31(28), 7250-7256. doi:10.1016/j.biomaterials. 2010.05.055

24. Han, Y., Wang, F., Wang, H., Jiao, X. ve Chen, D. (2018). High-strength boehmite-acrylate composites for 3D printing: Reinforced filler-matrix interactions. Composites Science and Technology, 154, 104-109. doi:10.1016/j.compscitech.2017.10.026

25. Hanssen, J., Moe, Z. H., Tan, D. ve Chien, O. Y. (2013). Rapid Prototyping in Manufacturing. Handbook of Manufacturing Engineering and Technology, 1-16.

26. Hornbeck, L. J. (1991). U.S. Patent No. 5,061,049. Washington, DC: U.S. Patent and Trademark Office.

27. http://www.3dnatives.com/en/polyjet100420174/, Erişim Tarihi: 07.08.2018, Konu: Polijet teknolojisi.

28. https://amtech3d.com/3d-printing-techniques/, Erişim Tarihi: 02.06.2019, Konu: Direk Işılk İsleme.

29. http://www.custompartnet.com/wu/fused-deposition-modeling/, Erişim Tarihi: 02.06.2019, Konu: Eriyik Yığarak Modelleme.

30. https://prattparametrics.com/2017/09/18/3d-printing-research-6/, Erişim Tarihi: 02.06.2019, Konu: $3 B$ baskı teknolojileri.

31. https://www.sculpteo.com/media/ebook/State_of_3DP_2018.pdf, Erişim Tarihi: 10.11. 2018, Konu: 3B baskı teknolojileri.

32. Huang, R., Riddle, M., Graziano, D., Warren, J., Das, S., Nimbalkar, S. ve Masanet, E. (2016). Energy and emissions saving potential of additive manufacturing: the case of lightweight aircraft components. Journal of Cleaner Production, 135, 1559-1570. doi:10.1016/j.jclepro.2015.04.109

33. Hull, C. W. (1986). U.S. Patent No. 4,575,330. Washington, DC: U.S. Patent and Trademark Office. 
34. Jacobs, P. F. (1992). Fundamentals of stereolithography. 1992 International Solid Freeform Fabrication Symposium.

35. Kang, H. W., Lee, S. J., Ko, I. K., Kengla, C., Yoo, J. J. ve Atala, A. (2016). A 3D bioprinting system to produce human-scale tissue constructs with structural integrity. Nature biotechnology, 34(3), 312. doi:10.1038/nbt.3413

36. Khan, H. M., Dirikolu, M. H., \& Koç, E. (2018). Parameters optimization for horizontally built circular profiles: Numerical and experimental investigation. Optik, 174, 521-529. doi: 10.1016/j.ijleo.2018.08.095

37. Kim, M. K., Kim, J. H., Park, S. E. ve BACK, S. A. (2018). U.S. Patent Application No. $15 / 745,736$.

38. Krinitcyn, M., Fu, Z., Harris, J., Kostikov, K., Pribytkov, G. A., Greil, P. ve Travitzky, N. (2017). Laminated Object Manufacturing of in-situ synthesized MAX-phase composites. Ceramics International, 43(12), 9241-9245. doi:10.1016/j.ceramint.2017.04 .079

39. Kumar, S., Choudhary, A. K. S., Singh, A. K., Gupta, A. K., Kumar, S., Choudhary, A. K. S. ve Gupta, A. K. (2016). A Comparison of Additive Manufacturing Technologies. IJIRST-International Journal for Innovative Research in Science ve Technology, 3(01), 06.

40. Lipton, J. I., Cutler, M., Nigl, F., Cohen, D. ve Lipson, H. (2015). Additive manufacturing for the food industry. Trends in food science ve technology, 43(1), 114-123. doi:10.1016/j.tifs.2015.02.004

41. Long, J., Gholizadeh, H., Lu, J., Bunt, C. ve Seyfoddin, A. (2017). Application of fused deposition modelling (FDM) method of 3D printing in drug delivery, Current pharmaceutical design, 23(3), 433-439. doi:10.2174/1381612822666161026162707

42. Marković, V. ve Žıvković, P. (2016). 3D printing-challenges and perspectives, International Scientific Journal of Technical Sciences, 60-67.

43. McMenamin, P. G., Quayle, M. R., McHenry, C. R. ve Adams, J. W. (2014). The production of anatomical teaching resources using three-dimensional (3D) printing technology. Anatomical sciences education, 7(6), 479-486. doi:10.1002/ase.1475

44. Meiners, W., Wissenbach, K. ve Gasser, A. (2001). U.S. Patent No. 6,215,093. Washington, DC: U.S. Patent and Trademark Office.

45. Mostafaei, A., Stevens, E. L., Ference, J. J., Schmidt, D. E. ve Chmielus, M. (2017). Binder jet printing of partial denture metal framework from metal powder. Mater. Sci. Technol., 289-291. doi:10.7449/2017mst/2017/mst_2017_289_291

46. Murphy, S. V. ve Atala, A. (2014). 3D bioprinting of tissues and organs. Nature biotechnology, 32(8), 773. doi:10.1038/nbt.2958

47. Murr, L. E., Amato, K. N., Li, S. J., Tian, Y. X., Cheng, X. Y., Gaytan, S. M. ve Wicker, R. B. (2011). Microstructure and mechanical properties of open-cellular biomaterials prototypes for total knee replacement implants fabricated by electron beam melting. Journal of the mechanical behavior of biomedical materials,4(7), 1396-1411. doi:10.1016/j.jmbbm.2011.05.010

48. Ngo, T. D., Kashani, A., Imbalzano, G., Nguyen, K. T. ve Hui, D. (2018). Additive manufacturing (3D printing): A review of materials, methods, applications and challenges. Composites Part B: Engineering. doi:10.1016/j.compositesb.2018.02.012 
49. Niaki, M. K. ve Nonino, F. (2018). The Management of Additive Manufacturing. Springer.doi: 10.1007/978-3-319-56309-1

50. Oropallo, W. ve Piegl, L. A. (2016). Ten challenges in 3D printing, Engineering with Computers, 32(1), 135-148. doi:10.1007/s00366-015-0407-0

51. Ortes, F., Surmen, H. K. ve Arslan, Y. Z. (2016). A biomechatronic application on prosthetics for undergraduate engineering students. The Eurasia Proceedings of Educational \& Social Sciences, 4, 461-464.

52. Panwar, A. ve Tan, L. P. (2016). Current status of bioinks for micro-extrusion-based 3D bioprinting. Molecules, 21(6), 685. doi:10.3390/molecules21060685

53. Ramya, A. ve Vanapalli, S. L. (2016). 3D printing technologies in various applications. International Journal of Mechanical Engineering and Technology, 7(3), 396409.

54. Richardson, M. ve Haylock, B. (2012). Designer/maker: the rise of additive manufacturing, domestic-scale production and the possible implications for the automotive industry. Computer-Aided Design ve Applications PACE, 2, 33-48. doi: 10.3722/cadaps. 2012.pace.33-48

55. Singh, S., Ramakrishna, S. ve Singh, R. (2017). Material issues in additive manufacturing: A review. Journal of Manufacturing Processes, 25, 185-200. doi:10.1016/j.jmapro.2016 .11 .006

56. Swanson, W. J., Mannella, D. F. ve Schloesser, R. G. (2013). U.S. Patent No. 8,459, 280. Washington, DC: U.S. Patent and Trademark Office.

57. Tack, P., Victor, J., Gemmel, P. ve Annemans, L. (2016). 3D-printing techniques in a medical setting: a systematic literature review. Biomedical engineering online, 15(1), 115. doi:10.1186/s12938-016-0236-4

58. Tumbleston, J. R., Shirvanyants, D., Ermoshkin, N., Janusziewicz, R., Johnson, A. R., Kelly, D. ve Samulski, E. T. (2015). Continuous liquid interface production of 3D objects. Science, 2397. doi:10.1126/science.aaa2397

59. Udroiu, R., ve Braga, I. C. (2017). Polyjet technology applications for rapid tooling, MATEC Web of Conferences, 112, 3011. doi:10.1051/matecconf/201711203011

60. Vaezi, M., Seitz, H. ve Yang, S. (2013). A review on 3D micro-additive manufacturing technologies. The International Journal of Advanced Manufacturing Technology, 67(5-8), 1721-1754. doi:10.1007/s00170-013-4962-5

61. Vaupotic, B., Brezocnik, M. ve Balic, J. (2006). Use of PolyJet technology in manufacture of new product. Journal of Achievements in Materials and Manufacturing Engineering, 18(1-2), 319-322.

62. Wang, Y. C., Chen, T. ve Yeh, Y. L. (2018). Advanced 3D printing technologies for the aircraft industry: a fuzzy systematic approach for assessing the critical factors. The International Journal of Advanced Manufacturing Technology, 1-11. doi:10.1007/s00170018-1927-8

63. Wohlers Report 2018, 2018. Wohlers Associates.

64. Wohlers, T. ve Gornet, T. (2014). History of additive manufacturing. Wohlers report, 24(2014), 118.

65. Wong, K. V. ve Hernandez, A. (2012). A review of additive manufacturing. ISRN Mechanical Engineering. 2012. doi:10.5402/2012/208760 
66. Wu, W., Jiang, J., Jiang, H., Liu, W., Li, G., Wang, B. ve Zhao, J. (2018). Improving bending and dynamic mechanics performance of 3D printing through ultrasonic strengthening. Materials Letters, 220, 317-320. doi:10.1016/j.matlet.2018.03.048

67. Yan, X. ve Gu, P. E. N. G. (1996). A review of rapid prototyping technologies and systems. Computer-Aided Design, 28(4), 307-318. doi:10.1016/0010-4485(95)00035-6

68. Yang, Y. ve Li, L. (2018). Cost modeling and analysis for Mask Image Projection Stereolithography additive manufacturing: Simultaneous production with mixed geometries. International Journal of Production Economics, 206, 146-158. doi:10.1016 /j.ijpe.2018.09.023

69. Zhang, B., Luo, Y., Ma, L., Gao, L., Li, Y., Xue, Q. ve Cui, Z. (2018). 3D bioprinting: an emerging technology full of opportunities and challenges. Bio-Design and Manufacturing, 1-12. doi:10.1007/s42242-018-0004-3

70. Zhang, Z. Y., Jhong, K. J., Cheng, C. W., Huang, P. W., Tsai, M. C. ve Lee, W. H. (2016). Metal 3D printing of synchronous reluctance motor. Industrial Technology (ICIT), 2016 IEEE International Conference, 1125-1128. doi:10.1109/icit.2016.7474912 